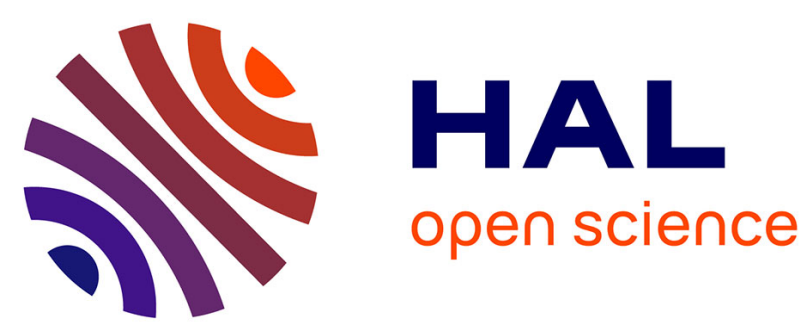

\title{
Salivary Gland Mucoepidermoid Carcinoma is a Clinically, Morphologically and Genetically Heterogeneous Entity. A Clinicopathologic Study of 40 Cases with Emphasis on Grading, Histological Variants and Presence of the $t(11 ; 19)$ Translocation.
}

Stephan Schwarz, Clemens Stiegler, Maximilian Mueller, Tobias Ettl, Gero Brockhoff, Johannes Zenk, Abbas Agaimy

\section{- To cite this version:}

Stephan Schwarz, Clemens Stiegler, Maximilian Mueller, Tobias Ettl, Gero Brockhoff, et al.. Salivary Gland Mucoepidermoid Carcinoma is a Clinically, Morphologically and Genetically Heterogeneous Entity. A Clinicopathologic Study of 40 Cases with Emphasis on Grading, Histological Variants and Presence of the t(11;19) Translocation.. Histopathology, 2011, 58 (4), pp.557. 10.1111/j.13652559.2011.03777.x . hal-00618804

\author{
HAL Id: hal-00618804 \\ https://hal.science/hal-00618804
}

Submitted on 3 Sep 2011

HAL is a multi-disciplinary open access archive for the deposit and dissemination of scientific research documents, whether they are published or not. The documents may come from teaching and research institutions in France or abroad, or from public or private research centers.
L'archive ouverte pluridisciplinaire HAL, est destinée au dépôt et à la diffusion de documents scientifiques de niveau recherche, publiés ou non, émanant des établissements d'enseignement et de recherche français ou étrangers, des laboratoires publics ou privés. 


\section{Histopathology}

\section{Salivary Gland Mucoepidermoid Carcinoma is a Clinically, Morphologically and Genetically Heterogeneous Entity. A Clinicopathologic Study of $\mathbf{4 0}$ Cases with Emphasis on Grading, Histological Variants and Presence of the $t(11 ; 19)$ Translocation.}

\begin{tabular}{|r|l|}
\hline Journal: & Histopathology \\
\hline Manuscript ID: & HISTOP-01-10-0044.R1 \\
\hline Manuscript Type: & Original Article \\
\hline Dathor: & 26-Apr-2010 \\
\hline Complete List of Authors: & $\begin{array}{l}\text { Schwarz, Stephan; Universitaetsklinikum Erlangen, Department of } \\
\text { Pathology } \\
\text { Stiegler, Clemens; University of Regensburg, Department of } \\
\text { Pathology } \\
\text { Mueller, Maximilian; Universitaetsklinikum Erlangen, Department of } \\
\text { Pathology } \\
\text { Ettl, Tobias; University of Regensburg, Department of Oral and } \\
\text { Maxillofacial Surgery } \\
\text { Brockhoff, Gero; University of Regensburg, Department of } \\
\text { Gynecology and Obstetrics } \\
\text { Zenk, Johannes; Universitaetsklinikum Erlangen, Department of } \\
\text { Oto-Rhino-Laryngology } \\
\text { Agaimy, Abbas; Universitaetsklinikum Erlangen, Department of } \\
\text { Pathology }\end{array}$ \\
\hline Keywords: & $\begin{array}{l}\text { mucoepidermoid carcinoma, variant, t(11;19), salivary gland, } \\
\text { grading }\end{array}$ \\
\hline \hline
\end{tabular}

\section{\$) ScholaronE" \\ Manuscript Central}


Salivary Gland Mucoepidermoid Carcinoma is a Clinically, Morphologically and Genetically Heterogeneous Entity. A Clinicopathologic Study of 40 Cases with Emphasis on Grading, Histological Variants and Presence of the $t(11 ; 19)$ Translocation.

Stephan Schwarz, M.D. ${ }^{1 *}$, Clemens Stiegler ${ }^{2 \star}$, Maximilian Müller ${ }^{1}$, Tobias Ettl, M.D., D.M.D. ${ }^{3}$, Gero Brockhoff, Ph.D. ${ }^{4}$, Johannes Zenk, M.D. ${ }^{5}$, and Abbas Agaimy, M.D. ${ }^{1}$

${ }^{1}$ Department of Pathology, University of Erlangen, Germany

2 Department of Pathology, University of Regensburg, Germany

${ }^{3}$ Department of Oral and Maxillofacial Surgery, University of Regensburg, Germany

${ }^{4}$ Department of Gynecology and Obstetrics, University of Regensburg, Germany

${ }^{5}$ Department of Oto-Rhino-Laryngology, University of Erlangen, Germany.

*These two authors have contributed equally.

Corresponding author:

Stephan Schwarz, MD,

Department of Pathology

University of Erlangen

Krankenhausstrasse 12

91054 Erlangen

Germany

Phone: +49-9131-8522288

Fax: +49-9131-8524745

stephan.schwarz@uk-erlangen.de 


\section{ABSTRACT}

Aims: To correlate World Health Organization (WHO) grade, patient's outcome and presence of $\mathrm{t}(11 ; 19)$ to histological tumor variants in 40 well characterized mucoepidermoid carcinomas (MECs) out of a series of 290 salivary gland carcinomas.

Methods and Results: MECs were classified as classical based on the presence of equal proportions of the three cell types or the dominance $(\geq 50 \%)$ of mucous cells beside at least one other cell type, and as variant if composed of $\geq 80 \%$ single cell type. Classical MECs were more common $(n=23)$. Variant MECs had predominant squamoid $(n=9)$, eosinophilic $(n=5)$, or clear cell $(n=3)$ morphology. 27 tumors were WHO grade 1,3 grade 2 and 10 grade 3 . The $t(11 ; 19)$ was detected in $82 \%, 35 \%$ and $0 \%$ of classical MEC, variant MEC and non-MEC, respectively. Classical MECs were significantly associated with age $\leq 60$ years $(p<0.001)$, grade $1(p<0.001)$, and $\mathrm{t}(11 ; 19)(p=0.003)$. Short overall survival was significantly associated with age $>60$ years $(p=0.001)$ and UICC stage $>I(p=0.031)$, residual tumor $(p<0.001)$, tumor grade $>1(p=0.001)$ and squamoid variant $(p=0.002)$ in Kaplan-Meier analysis.

Conclusions: The results underscore the great histological diversity of MEC, the reproducibility of the $\mathrm{WHO}$ grading and the value of histological subtypes as an additional prognostic factor.

\section{KEY WORDS}

Mucoepidermoid carcinoma; variant; $\mathrm{t}(11 ; 19)$; salivary gland; grading.

\section{INTRODUCTION}

Mucoepidermoid carcinoma (MEC) is the most common primary carcinoma of major and minor salivary glands accounting for about one third of all salivary carcinomas. ${ }^{1,2}$ MECs are composed of three cell types in varying proportion: mucous cells, epidermoid (squamoid) cells and undifferentiated small cells (intermediate cells). Any of these cell types may dominate the histological picture in a given tumor, thus posing great diagnostic difficulties. ${ }^{1}$ Traditionally, special stains like Meyer's mucicarmine and periodic acid-Schiff (PAS) are used for detection of sparse mucous cells. 
Currently, immunohistochemistry proved also of value in recognizing foci of intermediate and epidermoid cells and, in particular, in differentiating MECs from other salivary gland carcinomas that they may closely mimic. ${ }^{3,4}$

Owing to the highly variable biological behavior of MEC, a variety of prognostic factors have been evaluated on previous large series to predict aggressive tumor behavior and hence the necessity of more aggressive treatment. ${ }^{5,6}$ Of these, histological grading has received special attention and several grading systems have been proposed. ${ }^{7-9}$ While the difference in behavior of grade 1 and grade 3 MEC was universally confirmed in different studies, the results with regard to intermediategrade MEC have been inconsistent and varied from low-grade behavior ${ }^{10}$ to an aggressive course comparable to high-grade tumors ${ }^{11}$ or something in between. ${ }^{7}$ The Armed Forces Institute of Pathology (AFIP) system showed a higher reproducibility and was considered valid in the current World Health Organization (WHO) classification of head and neck tumors. ${ }^{1,7,8}$ However, Brandwein et al. suggested that the AFIP grading system may downgrade some MEC. ${ }^{12}$ They proposed considering histological features including infiltration pattern at the invasive front, vascular invasion and bony infiltration in the assessment of tumor grade.

The translocation $t(11 ; 19)$ has been detected in approximately half of MECs in several studies. ${ }^{13-15}$ However, data on the detection of this molecular alteration in Warthin tumor have been conflicting in different studies. ${ }^{16-18}$ Presence of $t(11 ; 19)$ was found to correlate with a better outcome in MEC, ${ }^{13,19,20}$ but the explanation for this is still lacking. To our knowledge, the correlation of well defined histological variants with WHO grading, patient outcome and the presence or absence of the translocation $t(11 ; 19)$ has not been evaluated previously. This was the objective of this study.

\section{MATERIAL AND METHODS}

\section{Patients and tumor samples}

Fourty MECs were retrieved from a consecutive collection of well characterized primary salivary gland carcinomas of both major and minor salivary glands (total $\mathrm{n}=290$ ) with complete follow-up treated at the Universities of Erlangen and Regensburg, Germany, or at the City Hospital of Nuremberg, Germany, between 1990 and 2007. Clinical information was obtained from the clinical tumor registries of 
Erlangen-Nuremberg and Regensburg as well as from the salivary gland carcinoma registry of Erlangen. The registries and the related translational research activities are covered by ethical vota of the medical faculties of the Universities of Regensburg and Erlangen-Nuremberg.

\section{Histology and classification}

On the basis of Hematoxylin and Eosin (H\&E) and PAS stained slides from at least subtotally embedded tumors all of the 290 tumors have been independently reviewed by two pathologists experienced in salivary gland tumor pathology (S. S. \& A. A.) without knowledge of initial histological diagnosis, FISH results or clinical follow-up. A few cases $(n=4)$ were either found to represent other types of salivary gland carcinomas or they were lacking unequivocal MEC areas, hence they were excluded. An agreement was achieved in 40 cases which represented the cohort of the current study.

MECs were diagnosed according to the well established WHO criteria. ${ }^{1}$ Furthermore, tumors have been categorized as either classical MEC or variant (non-classical) MEC. Classical MECs were tri- or biphasic neoplasms composed of well recognizable mucous cells (prominent single goblet cells or contiguous goblet cells forming mucinous gland-like or cystic spaces) in addition to variable proportions of epidermoid (squamoid) and intermediate cells. In contrast to true squamous cells, epidermoid cells lacked intercellular bridges and intracellular keratinization. Intermediate cells were small undifferentiated cells with round nuclei and scant basophilic cytoplasm. In difficult cases additional immunohistochemical staining for low $(\mathrm{CK} 7)^{21}$ or high molecular weight (CK5) cytokeratins was used to identify mucous, intermediate and epidermoid differentiation, respectively. CK5 antibody was purchased from Zytomed systems Ltd., Berlin, Germany, CK7 antibody from DCS Innovative Diagnostik-Systeme Dr. Christian Sartori Ltd., Hamburg, Germany. Immunostaining was performed on $5 \mu \mathrm{m}$ sections according to the manufacturer's instructions. Generally, all three components were well recognizable in each lowpower field in classical MECs. Biphasic tumors were considered classical if a prominent mucous component $(\geq 50 \%)$ was present beside another one (either intermediate or epidermoid cell component). The presence or absence of a prominent cystic component did not influence this classification. The presence of a focus of classical MEC in an otherwise variant MEC was judged according to the extent of 
both components. Tumors with $\geq 80 \%$ variant histology were considered variant MECs in this study. Applying the WHO criteria ${ }^{1}$ all tumors have been graded independently by the two pathologists, thereby showing a complete reproducibility in all cases.

\section{Tissue microarray construction}

A tissue microarray (TMA) was constructed from formalin-fixed paraffin-embedded tissue blocks of these 40 patients, and of additional 250 patients with salivary gland carcinomas others than MEC as well as of 60 cases of normal salivary gland tissue, as previously described. ${ }^{22,23}$ One tissue cylinder with a diameter of $2.0 \mathrm{~mm}$ was punched from morphologically representative tissue areas of each donor tissue block and brought into a recipient paraffin block using a homemade semiautomated tissue arrayer. TMA sections were mounted on charged slides (SuperFrost ${ }^{\mathrm{TM}} \mathrm{Plus}$; Menzel GmbH, Braunschweig, Germany). H\&E-stained TMA sections were used for reference histology.

\section{Fluorescence in situ hybridization}

Fluorescence in situ hybridization (FISH) was performed on $5 \mu \mathrm{m}$ sections of the TMAs using commercially available, directly labeled DNA break-apart probes to detect the translocation $\mathrm{t}(11 ; 19)$ (ZytoVision Ltd., Bremerhaven, Germany). The probes identifiy two locus specific sequences on chromosomes 11 (orange/green) spanning the break point at 11q21 and resulting in a yellow appearing fusion signal. A translocation was evident if the fusion signal was split into an orange and a green signal. TMA sections were dewaxed for $40 \mathrm{~min}$ in an incubator at $72{ }^{\circ} \mathrm{C}$ and for $2 \times$ $10 \mathrm{~min}$ in xylene. After being rehydrated in a graded ethanol series and rinsed in distilled water, slides were placed in $0.01 \mathrm{M}$ sodium citrate and steamed for 40 min in a water bath. Cell structures were digested in $0.1 \%$ pepsin (Sigma) and $0.01 \mathrm{M} \mathrm{HCL}$ for 10 min at $37^{\circ} \mathrm{C}$. After washing in $2 \times$ standard sodium citrate (SSC) $(1 \times \mathrm{SSC}$ is $150 \mathrm{mM}$ sodium chloride and $15 \mathrm{mM}$ sodium citrate, $\mathrm{pH}$ 7) and water, slides were dehydrated in graded alcohols and air-dried. $10 \mathrm{~mL}$ of the DNA probe set were applied to the TMA area of each section. Sections were cover-slipped and the edges sealed with rubber cement. For co-denaturation of the probe and target DNA, slides were placed on a hotplate preheated to $73^{\circ} \mathrm{C}$ for $5 \mathrm{~min}$ and transferred to a warmed hybridization chamber at $37^{\circ} \mathrm{C}$ overnight. 
After hybridization, the rubber cement was removed and the slides were immersed in $4 \times$ SSC $+0.3 \%$ Igepal (Serva), $2 \times$ SSC, and $1 \times$ SSC for 10 min at $50 \stackrel{\circ}{C}$, respectively. The slides were rinsed briefly in Millipore water and air-dried. Nuclei were counterstained with anti-fading DAPI (4',6-diamidino-2-phenylindole) Vectashield (Vector Laboratories, Burlingame, CA, USA) and were analyzed by epifluorescence microscopy.

Microscopy, FISH scoring, and digital imaging slides were imaged with an Axio Imager Z.1 (Zeiss, Göttingen, Germany) equipped with specific filter sets for DAPI (excitation $365 \pm 20 \mathrm{~nm}$, emission $450 \pm 25 \mathrm{~nm}$; Zeiss), green (excitation $500 \pm 10$ $\mathrm{nm}$, emission $535 \pm 15 \mathrm{~nm}$ ), and red fluorescence (excitation $545 \pm 15 \mathrm{~nm}$, emission $610 \pm 35$ nm; AHF, Tübingen, Germany). Fluorescence images were obtained with a Plan-Apochromat lens $(63 \times, 1.4)$ and recorded with a charge-coupled device (CCD) camera AxioCam MRm (Zeiss). FISH scoring was performed by counting fluorescence signals in 50 malignant, non-overlapping cell nuclei for each case by two independent interpreters (CS, MM). A tumor was considered positive if $>50 \%$ of the cells harbored the translocation.

\section{Statistical analyses}

All clinicopathologic and cytogenetic data were analyzed with SPSS for Windows, version 15.0 (SPSS, Erkrath, Germany). Relationships between dichotomized histological or cytogenetic markers and clinicopathologic factors were examined using Fisher's exact probability test (significant association with $p<0.05$ ). Overall survival (= primary outcome measure) was calculated as the time from the date of diagnosis to death from any cause or the date the patient was last known to be alive. Patients lost to follow-up were treated as censored cases based on the date they were last known to be alive. Survival curves were generated by using the KaplanMeier method, and log-rank tests compared the distributions between groups. For multivariate analysis a Cox proportional hazards model was used in a backwards, stepwise elimination approach. At each step the least significant factor with $p>0.10$ was eliminated with reassessment of each factor in the model at each step. A limit for the factors to be included was set at $5 \%$.

\section{RESULTS}

\section{Clinical features of MEC}


The clinicopathologic parameters are summarized in Tables 1 and 2. Using the current WHO criteria for grading salivary gland MEC, ${ }^{1} 27$ cases were low grade (G1), 3 cases were intermediate grade (G2) and 10 cases were high grade (G3). Classical MEC was significantly associated with age $\leq 60$ years $(p=<0.001)$, grade 1 ( $p=$ $<0.001)$ and presence of the translocation $\mathrm{t}(11 ; 19)(p=0.003)$.

Mean follow up was 64.5 months (range 1.6-224 months). Ten patients (25\%) died of their tumors at a mean interval of 25.2 months (range 1.6-70.9 months).

\section{Histological features of MEC}

\section{Classical MEC}

Twenty-three tumors fulfilled the above criteria of classical MEC. These revealed variable cystic areas; a prominent cystic component $(>20 \%)$ was seen in 7 tumors. Mucous cells were prominent in each low-power field and gland-like spaces or aggregates of contiguous mucous cells were well discernible even at low power magnification (Fig. 1A). Focal unusual features in classical MEC included minor components with microvesicular cytoplasm suggesting abortive sebaceous differentiation (two cases; Fig. 1B), focal syncytial overgrowth of spindled intermediate cells reminiscent of myoepithelial differentiation but lacking expression of p63 and CK5 (expressing CK7 diffusely) (Fig. 1C-D) and circumscribed tumor nests composed of peripherally located polygonal myoepithelial-like clear cells punctuated by centrally located small microcystic glands mimicking epithelialmyoepitheial carcinoma (EMC) (Fig. 1E-F). However, the lumina were lined by flattened epithelial cells and lacked the well discernible glands of EMC. Furthermore and interestingly, immunohistochemistry showed the reverse of EMC with CK5 being expressed in the luminal cells and CK7 in the outer layer, thus adopting an "inverted EMC pattern" (Fig. 1E-F). A common finding in several cases was the presence of atypical looking preexisting salivary duct showing both bland-looking ciliated epithelium and crypt-like mucous cell hyperplasia resulting in atypical budding of mucous cell-rich ductules and small solid nests of intermediate cells (Fig. 1G-H). These changes were often associated with an avascular papillary epithelial tufting.

\section{Squamoid (epidermoid) MEC}

Squamoid tumors $(n=9)$ showed variable degree of squamoid differentiation with horn cysts and sharp intercellular junction, but prominent intercellular bridges as seen in 
typical squamous cell carcinoma were lacking. Occasional cytoplasmic vacuoles, possibly representing abortive glandular differentiation, were seen. A few tumors revealed a focal or prominent acantholytic (pseudoglandular or pseudovascular) pattern. Another pattern seen in this group was the presence of differentiated sqamoid sheets with numerous microcystic lumina filled with blue mucin and imparting a pseudocribriform pattern to the tumor (Fig. 2A-B). One tumor classified into this subtype showed solid sheets of medium-sized to relatively small basophilic cells with histological and immunohistochemical features of intermediate cells with minor component of mucous cells (Fig. 2C-D). This tumor would be better categorized as variant MEC of intermediate cell type, but no more cases were found to warrant an additional subtype and the case was hence discussed under the subheading of squamoid MEC.

\section{Eosinophilic (oncocytoid) MEC}

This represented the second most common type of variant MEC $(n=5)$. Tumors in this group showed a predominance of medium-sized to large cells with deeply eosinophilic cytoplasm lacking equivocal squamoid differentiation (Fig. 3A-B). Tumor cells revealed either a prominent glandular differentiation that closely resembled mature striated ducts (Fig. 3C) or they were arranged into solid sheets and possessed prominent centrally located nuclei, thus strikingly mimicking an oncocytic neoplasm (Fig. 3D). Occasionally, both features were seen side-by-side. In addition, all tumors showed either minor classical MEC areas, focal epidermoid/squamoid differentiation or scattered mucous cells, thus establishing the diagnosis of MEC (Fig. 3E-F). The tumor illustrated in Fig. 3A was composed of large atypical cystic glands lined by oncocytic partially ciliated cells with occasional papillary pattern reminiscent of Warthin tumor. Single striated duct-like glands seemed to bud off the cyst. However, mucous cells and other typical features were evident in small areas of the tumor. Furthermore, a lymphoid component was lacking and, instead, a hypervascularized stroma was seen.

\section{Clear cell MEC}

Although focal clear cell areas were quite common in MEC in general, the clear cell variant was the least common variant in our study $(n=3)$. Clear cell variants were composed of solid sheets of medium-sized polygonal cells with cytoplasmic clearing, 
usually with peripheral cytoplasmic retraction with occasional lightly eosinophilic staining tumor cell groups (Fig. 4A-B). The appearance of some of these tumors was reminiscent of the chromophobe renal cell carcinoma (Fig. 4C). The typical nesting and hyaline bands of clear cell carcinoma, not otherwise specified (NOS), was absent. Unequivocal mucous cells or minor foci of typical MEC were seen, thus establishing the diagnosis (Fig. 4B, D).

\section{Distribution and prognostic role of the translocation $t(11 ; 19)$ in MEC}

The $t(11 ; 19)$ was detected in 25 of the 40 MEC (62.5\%). This corresponded to 19/23 classical MEC (82.6\%) and 6/17 variant MEC (35\%). Among the different variant MEC types, the clear cell variant showed the highest, and the squamoid variant the lowest positivity rate $(100 \%$ versus $11 \%$, respectively). The eosinophilic variant showed an intermediate value (40\%). All of the non-MEC salivary carcinomas were translocation-negative. The closer association of the translocation with the classical type of MEC was significant $(p=0.003)$ as was the negative association with the squamoid variant $(p=0.001)$. As given in Table 2 the translocation significantly associated with low grade tumors $(p=0.01)$, but not with age, stage, presence of residual tumor, sex and localization. Although not significant, the occurrence of $t(11 ; 19)$ was a factor of better overall survival $(p=0.098)$.

\section{Associations of the histological variants with clinicopathologic parameters}

The different variants of MEC have been correlated with clinical parameters (age and tumor stage) as well as with tumor grade. The classical type predominated in younger patients with a mean age of 42 years (range 11-80 years, $p<0.001$ ) whereas the squamoid variant usually occurred in the elderly with a mean age of 68 years (range 37-94 years, $\mathrm{p}=0.03$ ). MECs of classical type were typically low grade (G1, $p<0.001)$, the squamoid variant was of intermediate or high grade $(p<0.001)$. Squamoid variant tended to occur more frequently in the major glands (parotid and submandibular gland) than in the minor glands of the oral cavity $(p=0.055)$. An association of the variants with sex and stage could not be demonstrated.

\section{Prognostic significance of clinicopathologic parameters in MEC}

To examine the prognostic significance of important clinicopathologic parameters in MEC, Kaplan-Meier analyses were applied (Figure 5). Here, short overall survival 
was significantly associated with age $>60$ years $(\mathrm{p}=0.001)$, high UICC stage (II, III, IV vs. I; $p=0.031)$, residual tumor after primary surgery $(p<0.001)$ and higher tumor grade ( $G 2$ and $G 3$ vs. $G 1 ; p=0.001$ ). Sex and localization did not significantly influence survival. The analysis of known clinicopathologic parameters was supplemented by a Kaplan-Meier analysis of the aforementioned histological variants of MEC. Here, the classical type of MEC was associated with best prognosis, whereas the non-classical MEC variants were significant negative prognosticators $(p=0.002)$.

The univariate Kaplan-Meier analysis was complemented by a multivariate Cox regression to examine the independence of the prognostically relevant clinicopathologic parameters. As the tumor variant was strongly associated with tumor grade (Table 1), the Cox regression analysis could not include both parameters. Thus, two analyses were performed: one with grade (grade 1 versus others) and one with variant (squamoid versus others). The other parameters to include into the analysis were those which proved to be of prognostic significance in univariate Kaplan-Meier analysis (Figure 5): age, stage and residual tumor. The Cox regression model (Table 3) was adjusted within two reverse steps in order to exclude a non significant parameter (stage). High age, higher grade, presence of residual tumor and squamoid variant remained significant prognostic factors with hazard ratios between 4.7 and 18.0 .

\section{DISCUSSION}

In this study, we analyzed the full histological spectrum of MEC in relation to tumor site, WHO-grade, stage, survival and the presence of the translocation $t(11 ; 19)$ in 40 well characterized MECs of major and minor salivary glands. Our findings underscore the diverse morphology of MEC which results from the striking variability in the proportion of the three cell types comprising the tumor. In its classical form, MEC shows a comparable proportion of three or of at least two cell types, hence the diagnosis of this classical variant is straight forward and usually poses no difficulty. However, a single cell type may constitute the bulk of the tumor, thus giving rise to monophasic variants of MEC, the diagnosis and true categorization of them may be challenging, even for those with great experience in salivary gland pathology. We 
have subclassified variant MEC into squamoid, eosinophilic and clear cell subtypes based on the presence of $>80 \%$ variant pattern in the tumor.

The squamoid subtype was the most common variant MEC in this study and implied commonly a high-grade tumor with significantly adverse outcome. The diagnosis of this variant may be facilitated by detection of minor foci of classical MEC through excessive tumor sampling and demonstration of isolated mucous cells or intracellular mucin assisted by special stains (mucicarmine, PAS). Also, the presence of a population of smaller cells lacking evident squamoid differentiation (intermediate cells) represents an important clue to diagnosis. Immunohistochemistry may help to recognize such minor foci that would remain undetected on initial H\&E evaluation. Adenosquamous carcinoma, which is actually not included into the WHO classification of salivary gland tumors, is an important differential diagnosis of the squamoid MEC. Demonstration of unequivocal mucous cells and/or intermediate cells on H\&E, mucin stains or by immunohistochemistry represents the main discriminator. In this setting, the $t(11 ; 19)$ may help to confirm the diagnosis of MEC in equivocal cases. Lennerz et al. detected the $t(11 ; 19)$-related rearrangements in 7 of 7 MECs of the uterine cervix, but in none of 14 conventional cervical adenosquamous carcinomas. ${ }^{24}$ However, sensitivity of $t(11 ; 19)$ for squamoid MEC is quite low in our study (11\%). Immunohistochemistry showed consistent expression of CK5 in squamoid MEC as well as in high grade $\mathrm{MEC}^{25}$. One tumor in this series showed a predominance of small blue-staining CK5-negative intermediate cells, suggesting the existence of an intermediate cell variant, but the clinical significance of this remains to be further studied in larger series. We discussed this single case within the spectrum of the squamoid variant.

Eosinophilic MEC (also known as oncocytoid MEC) ${ }^{26,27}$ shows increased cytoplasmic eosinophilia irrespective of growth pattern but some cases may appear oncocytoid as a result of prominent striated duct-like differentiation. ${ }^{28}$ The latter pattern is exceedingly rare and may mimic MEC arising in Warthin tumor. ${ }^{29}$ Although eosinophilic MEC may show a prominent papillary and cystic pattern, the two-layered pattern of oncocytic cells with centrally located nuclei and a prominent lymphoid stroma typical of Warthin tumor are lacking in de novo eosinophilic MEC. Furthermore, MEC ex Warthin tumor is usually of the classical type. ${ }^{29}$ On the other hand, eosinophilic MEC with papillary pattern and tumor-associated lymphoid 
proliferation has to be distinguished from benign Warthin tumor with squamous and/or mucous metaplasia and from so-called Warthin adenocarcinoma. ${ }^{30}$

The clear cell variant was generally reminiscent of the clear cell carcinoma, NOS. However, on careful evaluation, a variable, but generally minor population of intermediate cells or a minute focus of classical MEC may be detected. The $t(11 ; 19)$ proved helpful and sensitive in the current study in detecting this variant (3 of 3), but the small case number does not allow for solid conclusions. Of interest, focal clear cell change associated with a biphasic pattern very reminiscent of EMC was seen in one classical MEC. Immunohistochemistry revealed however an "inverted EMC pattern" with the luminal CK5 positivity and CK7 expression in the outer layer. Awareness of this finding, whether in classical or in clear cell MEC, should help to avoid misinterpretation as EMC.

Our results showed a high reproducibility of the current WHO grading ${ }^{1}$ which is based on the AFIP criteria. ${ }^{7,8}$ However, due to the relatively limited case number we could not assess, whether the WHO system downgrades MEC. In line with the observation of Brandwein et al., ${ }^{12}$ dominant histological pattern/ features of tumors correlated well with the tumor grade and outcome, thus suggesting that defining histological criteria should be included in the scoring/ grading of MEC. Non-classical variants tend to be of higher WHO grade than classical MEC, the latter were predominantly grade 1 tumors (96\%) compared to only $29 \%$ grade 1 variant MEC. A comparable statistical significance value $(p<0.001)$ was demonstrated for WHO grade 1 and classical variant in the association analysis indicating that recognition of the classical variant implies a grade 1 tumor.

One interesting finding in this study was the occurrence of atypical crypt-like mucous cell hyperplasia and foci of intermediate-like cells associated with residual salivary duct in several cases of classical MEC. This finding probably represents a putative precursor lesion, but reactive changes induced by the tumor as well as secondary colonization of preexisting ducts by tumor cells can not be reliably excluded. However, in the experience of the authors, this finding is not common in specimens harboring other-type salivary gland carcinomas, suggesting a precursor change specifically associated with mucoepidermoid neoplasms and arguing against a 
reactive ductal lesion, but this merits future studies. Williamson et al. described similar foci of squamous and mucous cell metaplasia associated with cytological atypia within oncocytic epithelium of Warthin tumor harboring MEC and speculated that these might represent precursor lesions for MEC. ${ }^{29}$

In summary, we analyzed 40 salivary MEC, demonstrating a high histological variation and showing that histological variant correlates well with the WHO tumor grade, biological behavior and presence of $t(11 ; 19)$. Future studies on larger series are needed to further verify the value of histological variant in supplementing tumor grading and predicting treatment failure.

\section{ACKNLOWLEDGEMENT}

The authors thank Prof Dr Peter Wünsch of the Nuremberg City Hospital for generously supplying paraffin blocks of his institution's MECs. They thank Mrs Marietta Bock and Mr Rudolf Jung for excellent technical assistance. They also thank Dr Sabrina Petsch, Tumor Center Erlangen-Nuremberg, and Dr Monika Klinkhammer-Schalke, Tumor Center Regensburg for yielding the clinical follow up data of the patients to the authors.

\section{REFERENCES}

1. Goode RK, El-Naggar, A.K. Mucoepidermoid carcinoma. In Barnes L, Eveson, J.W., Reichart, P., Sidransky D. ed. World Health Organization Classification of Tumours. Pathology and Genetics of Head and Neck Tumours. Lyon: IARC Press, 2005;219-220.

2. Eveson JW, Cawson RA. Salivary gland tumours. A review of 2410 cases with particular reference to histological types, site, age and sex distribution. J. Pathol. 1985;146;51-58.

3. de Araujo VC, de Sousa SO, Carvalho YR, de Araujo NS. Application of immunohistochemistry to the diagnosis of salivary gland tumors. Appl. Immunohistochem. Mol. Morphol. 2000;8;195-202. 
4. Rizkalla H, Toner M. Necrotizing sialometaplasia versus invasive carcinoma of the head and neck: the use of myoepithelial markers and keratin subtypes as an adjunct to diagnosis. Histopathology 2007;51;184-189.

5. Ettl T, Schwarz S, Kleinsasser N, Hartmann A, Reichert TE, Driemel O. Overexpression of EGFR and absence of C-KIT expression correlate with poor prognosis in salivary gland carcinomas. Histopathology 2008;53;567-577.

6. Subramaniam MM, Ng SB, Seah SB, Anuar D, Soong R, Lee VK. Molecular characterization of dedifferentiated mucoepidermoid carcinoma of the trachea using laser microdissection-based TP53 mutation analysis. Histopathology 2009;55;472-475.

7. Auclair PL, Goode RK, Ellis GL. Mucoepidermoid carcinoma of intraoral salivary glands. Evaluation and application of grading criteria in 143 cases. Cancer 1992;69;2021-2030.

8. Goode RK, Auclair PL, Ellis GL. Mucoepidermoid carcinoma of the major salivary glands: clinical and histopathologic analysis of 234 cases with evaluation of grading criteria. Cancer 1998;82;1217-1224.

9. Luna MA. Salivary mucoepidermoid carcinoma: revisited. Adv. Anat. Pathol. 2006;13;293-307.

10. Nance MA, Seethala RR, Wang $Y$ et al. Treatment and survival outcomes based on histologic grading in patients with head and neck mucoepidermoid carcinoma. Cancer 2008;113;2082-2089.

11. Aro K, Leivo I, Makitie AA. Management and outcome of patients with mucoepidermoid carcinoma of major salivary gland origin: a single institution's 30-year experience. Laryngoscope 2008;118;258-262.

12. Brandwein MS, Ivanov K, Wallace DI et al. Mucoepidermoid carcinoma: a clinicopathologic study of 80 patients with special reference to histological grading. Am. J. Surg. Pathol. 2001;25;835-845.

13. Nakayama T, Miyabe S, Okabe M et al. Clinicopathological significance of the CRTC3-MAML2 fusion transcript in mucoepidermoid carcinoma. Mod. Pathol. 2009.

14. O'Neill ID. $\mathrm{t}(11 ; 19)$ translocation and CRTC1-MAML2 fusion oncogene in mucoepidermoid carcinoma. Oral Oncol. 2009;45;2-9. 
15. Behboudi A, Enlund F, Winnes $M$ et al. Molecular classification of mucoepidermoid carcinomas-prognostic significance of the MECT1-MAML2 fusion oncogene. Genes Chromosomes Cancer 2006;45;470-481.

16. Martins C, Cavaco B, Tonon G, Kaye FJ, Soares J, Fonseca I. A study of MECT1-MAML2 in mucoepidermoid carcinoma and Warthin's tumor of salivary glands. J. Mol. Diagn. 2004;6;205-210.

17. Bullerdiek J, Haubrich J, Meyer K, Bartnitzke S. Translocation $\mathrm{t}(11 ; 19)(\mathrm{q} 21 ; \mathrm{p} 13.1)$ as the sole chromosome abnormality in a cystadenolymphoma (Warthin's tumor) of the parotid gland. Cancer Genet. Cytogent. 1988;35;129-132.

18. Tirado Y, Williams MD, Hanna EY, Kaye FJ, Batsakis JG, El-Naggar AK. CRTC1/MAML2 fusion transcript in high grade mucoepidermoid carcinomas of salivary and thyroid glands and Warthin's tumors: implications for histogenesis and biologic behavior. Genes Chromosomes Cancer 2007;46;708-715.

19. Okabe M, Miyabe S, Nagatsuka $\mathrm{H}$ et al. MECT1-MAML2 fusion transcript defines a favorable subset of mucoepidermoid carcinoma. Clin. Cancer Res. 2006;12;3902-3907.

20. Miyabe S, Okabe M, Nagatsuka H et al. Prognostic significance of p27Kip1, Ki-67, and CRTC1-MAML2 fusion transcript in mucoepidermoid carcinoma: a molecular and clinicopathologic study of 101 cases. J. Oral Maxillofac. Surg. 2009;67;1432-1441.

21. Meer S, Altini M. CK7+/CK20- immunoexpression profile is typical of salivary gland neoplasia. Histopathology 2007;51;26-32.

22. Schwarz S, Bier J, Driemel O et al. Losses of 3p14 and 9p21 as shown by fluorescence in situ hybridization are early events in tumorigenesis of oral squamous cell carcinoma and already occur in simple keratosis. Cytometry $A$ 2008;73;305-311.

23. Milanes-Yearsley M, Hammond ME, Pajak TF et al. Tissue micro-array: a cost and time-effective method for correlative studies by regional and national cancer study groups. Mod. Pathol. 2002;15;1366-1373.

24. Lennerz JK, Perry A, Mills JC, Huettner PC, Pfeifer JD. Mucoepidermoid carcinoma of the cervix: another tumor with the $t(11 ; 19)$-associated CRTC1MAML2 gene fusion. Am. J. Surg. Pathol. 2009;33;835-843. 
25. Lueck NE, Robinson RA. High levels of expression of cytokeratin 5 are strongly correlated with poor survival in higher grades of mucoepidermoid carcinoma. J. Clin. Pathol. 2008;61;837-840.

26. Brannon RB, Willard CC. Oncocytic mucoepidermoid carcinoma of parotid gland origin. Oral Surg. Oral Med. Oral Pathol. Oral Radiol. Endod. 2003;96;727-733.

27. Weinreb I, Seethala RR, Perez-Ordonez B, Chetty R, Hoschar AP, Hunt JL. Oncocytic mucoepidermoid carcinoma: clinicopathologic description in a series of 12 cases. Am. J. Surg. Pathol. 2009;33;409-416.

28. Foschini MP, Marucci G, Eusebi V. Low-grade mucoepidermoid carcinoma of salivary glands: characteristic immunohistochemical profile and evidence of striated duct differentiation. Virchows Arch. 2002;440;536-542.

29. Williamson JD, Simmons BH, el-Naggar A, Medeiros LJ. Mucoepidermoid carcinoma involving Warthin tumor. A report of five cases and review of the literature. Am. J. Clin. Pathol. 2000;114;564-570.

30. Bell D, Luna MA. Warthin adenocarcinoma: analysis of 2 cases of a distinct salivary neoplasm. Ann. Diagn. Pathol. 2009;13;201-207.

\section{FIGURE LEGENDS}

Figure 1 Variations of classical (low-grade) mucoepidermoid carcinoma with unusual features. A Classical and partially cystic MEC composed of mucous, epidermoid and intermediate cells. B MEC with focal sebaceouslike differentiation characterized by polygonal cells with microvesicular cytoplasm. C MEC exhibiting partial overgrowth of spindle shaped intermediate cells mimicking myoepithelial differentiation but negative for myoepithelial markers (p63, not shown) and CK5 (D). E Classical MEC (G1) with focal clear cell change of intermediate cells, negative for CK5 (F), but positive for CK7 (not shown), generating an inverted epithelialmyoepithelial pattern. G Classical MEC entrapping a salivary duct with mucous metaplasia, possibly representing a precursor lesion of MEC. $\mathbf{H}$ 
Higher magnification demonstrating a proliferation of intermediate cells within the duct lumen on the right side and a focal eosinophilic change of epidermoid tumor cells on the left side.

Figure 2 Mucoepidermoid carcinoma of squamoid type. A High grade MEC (G3) with mucus filled microcystic spaces and sheets of intermediate cells differentiating to mature squamoid epithelia forming horn pearls. B Strong expression of $\mathrm{CK} 5$ in the intermediate/squamoid cells. This tumor was $\mathrm{t}(11 ; 19)$ negative. C High grade MEC (G3) predominantly composed of solid sheets of intermediate cells with interspersed single mucous cells. Partial expression of CK5 (D) and negativity of CK7 (not shown) indicate immature/intermediate cells. This tumor was $\mathrm{t}(11 ; 19)$ positive (not shown).

Figure 3 Mucoepidermoid carcinoma of eosinophilic (oncocytoid) type / with striated duct differentiation. A,B Cyst wall of a partially cystic MEC of eosinophilic type (G1) resembling a Warthin tumor with mucous metaplasia and without lymphoid stroma. The neoplastic tubules were strikingly similar to striated ducts of normal salivary gland. Translocation $\mathrm{t}(11 ; 19)$ was negative. C,D Another $\mathrm{t}(11 ; 19)$-positive low-grade MEC with striated duct differentiation (C) and solid cell sheets with characteristic oncocytic appearance (D). E Eosinophilic MEC with predominant sclerosis (sclerosing type eosinophilic MEC, G2). The tumor was composed of solid sheets of CK7-positive (F) intermediate cells with interspersed mucous cells and focal positivity for CK5 (not shown). This tumor was $\mathrm{t}(11 ; 19)$-negative.

Figure 4 Mucoepidermoid carcinoma of clear cell type. A low-grade MEC predominantly composed of solid sheets of clear cells with inconspicuous nuclei and "chromophobe" appearance. B a small focus with classical morphology detected on further sampling. C FISH using break-apart probes demonstrated translocation $\mathrm{t}(11 ; 19)$ indicated by split orange and green signals. D High grade clear cell MEC with higher nuclear pleomorphism and focal well differentiated areas (E). F FISH demonstrated polysomy 11 and bi- or tri-allelic translocation $\mathrm{t}(11 ; 19)$. 
Figure 5 Univariate Kaplan-Meier analyses of clinicopathologic parameters (sex, age, localization, type, UICC stage, residual tumor classification, grade, and translocation $t(11 ; 19)$ regarding overall survival (in months). $P$ values according to log rank statistics.

Table 1 Clinicopathologic parameters related to the four subtypes of MEC (Significance of associations was evaluated by Fisher exact test).

Table 2 Clinicopathologic parameters related to presence or absence of $t(11 ; 19)$. Significance of association was evaluated by Fisher exact test.

Table 3 Univariate and multivariate Cox regression with reverse stepwise selection. In the upper half age, stage, grade, and residual tumor are included, in the lower half grade is replaced by tumor type (squamoid vs. others). 

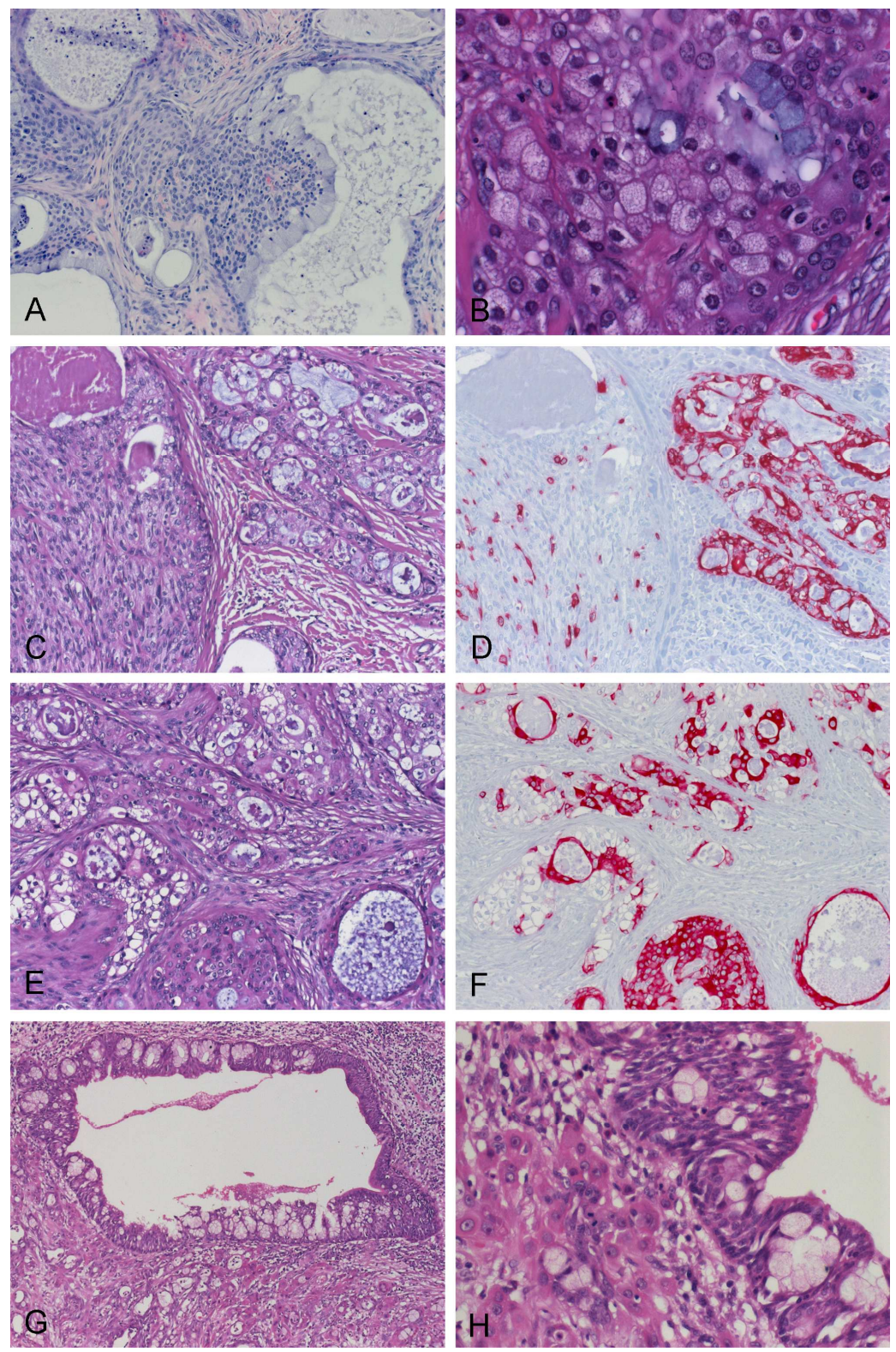

Variations of classical (low-grade) mucoepidermoid carcinoma with unusual features. A Classical and partially cystic MEC composed of mucous, epidermoid and intermediate cells. B MEC with focal sebaceous-like differentiation characterized by polygonal cells with microvesicular cytoplasm. C MEC exhibiting partial overgrowth of spindle shaped intermediate cells mimicking myoepithelial

differentiation but negative for myoepithelial markers ( $p 63$, not shown) and CK5 (D). E Classical MEC (G1) with focal clear cell change of intermediate cells, negative for CK5 (F), but positive for CK7 (not shown), generating an inverted epithelial-myoepithelial pattern. G Classical MEC entrapping a salivary duct with mucous metaplasia, possibly representing a precursor lesion of MEC. $\mathrm{H}$ Higher magnification demonstrating a proliferation of intermediate cells within the duct lumen on the right side and a focal eosinophilic change of epidermoid tumor cells on the left side.

$650 \times 987 \mathrm{~mm}(79 \times 79$ DPI) 

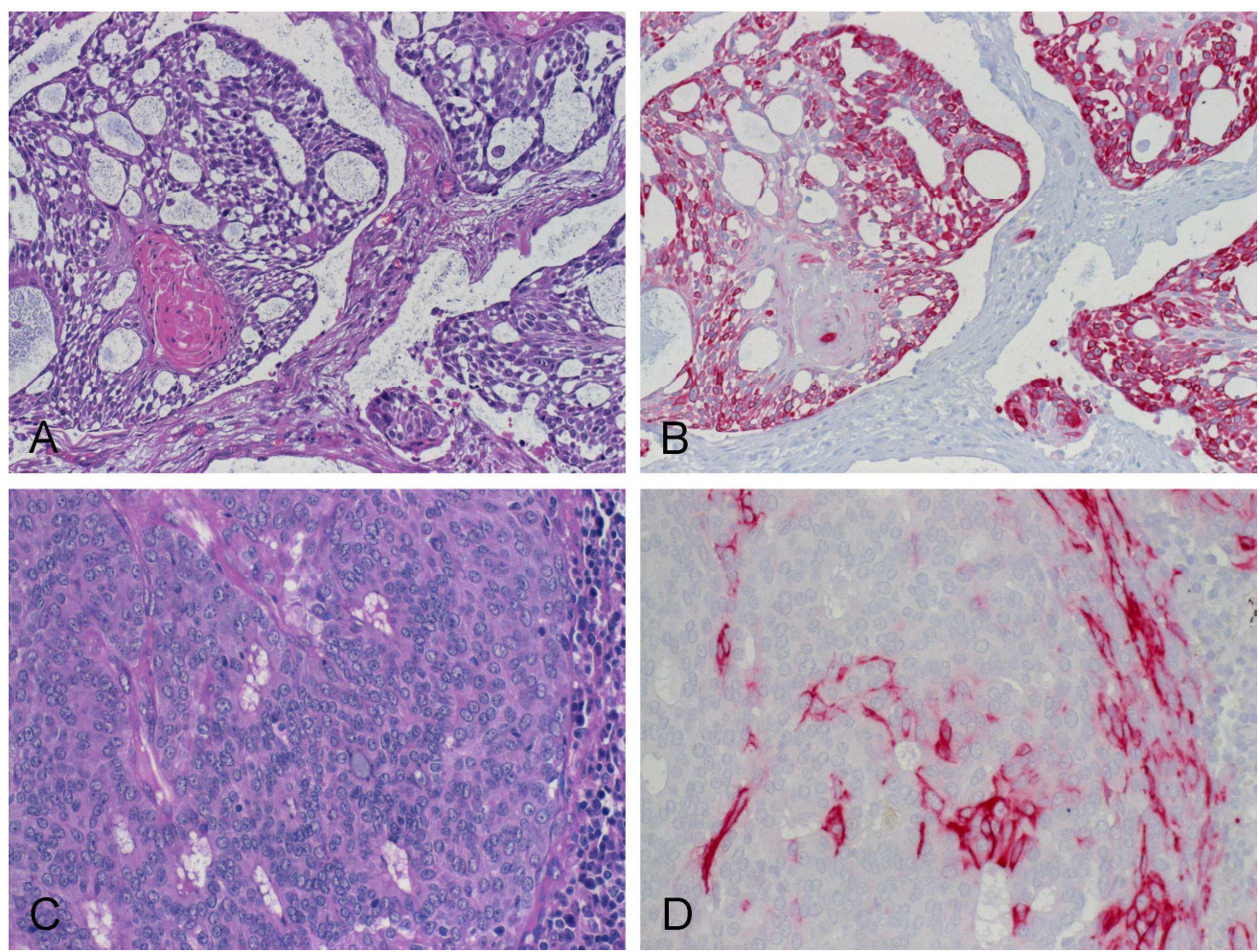

Mucoepidermoid carcinoma of squamoid type. A High grade MEC (G3) with mucus filled microcystic spaces and sheets of intermediate cells differentiating to mature squamoid epithelia forming horn pearls. B Strong expression of CK5 in the intermediate/squamoid cells. This tumor was $\mathrm{t}(11 ; 19)$ negative. C High grade MEC (G3) predominantly composed of solid sheets of intermediate cells with interspersed single mucous cells. Partial expression of CK5 (D) and negativity of CK7 (not shown) indicate immature/intermediate cells. This tumor was $\mathrm{t}(11 ; 19)$ positive (not shown). $647 \times 487 \mathrm{~mm}(96 \times 96 \mathrm{DPI})$ 



Mucoepidermoid carcinoma of eosinophilic (oncocytoid) type / with striated duct differentiation. A,B

Cyst wall of a partially cystic MEC of eosinophilic type (G1) resembling a Warthin tumor with

mucous metaplasia and without lymphoid stroma. The neoplastic tubules were strikingly similar to striated ducts of normal salivary gland. Translocation $\mathrm{t}(11 ; 19)$ was negative. C,D Another $\mathrm{t}(11 ; 19)$ positive low-grade MEC with striated duct differentiation (C) and solid cell sheets with characteristic oncocytic appearance (D). E Eosinophilic MEC with predominant sclerosis (sclerosing type eosinophilic MEC, G2). The tumor was composed of solid sheets of CK7-positive (F) intermediate cells with interspersed mucous cells and focal positivity for CK5 (not shown). This tumor was $\mathrm{t}(11 ; 19)$-negative.

$647 \times 736 \mathrm{~mm}(96 \times 96 \mathrm{DPI})$ 

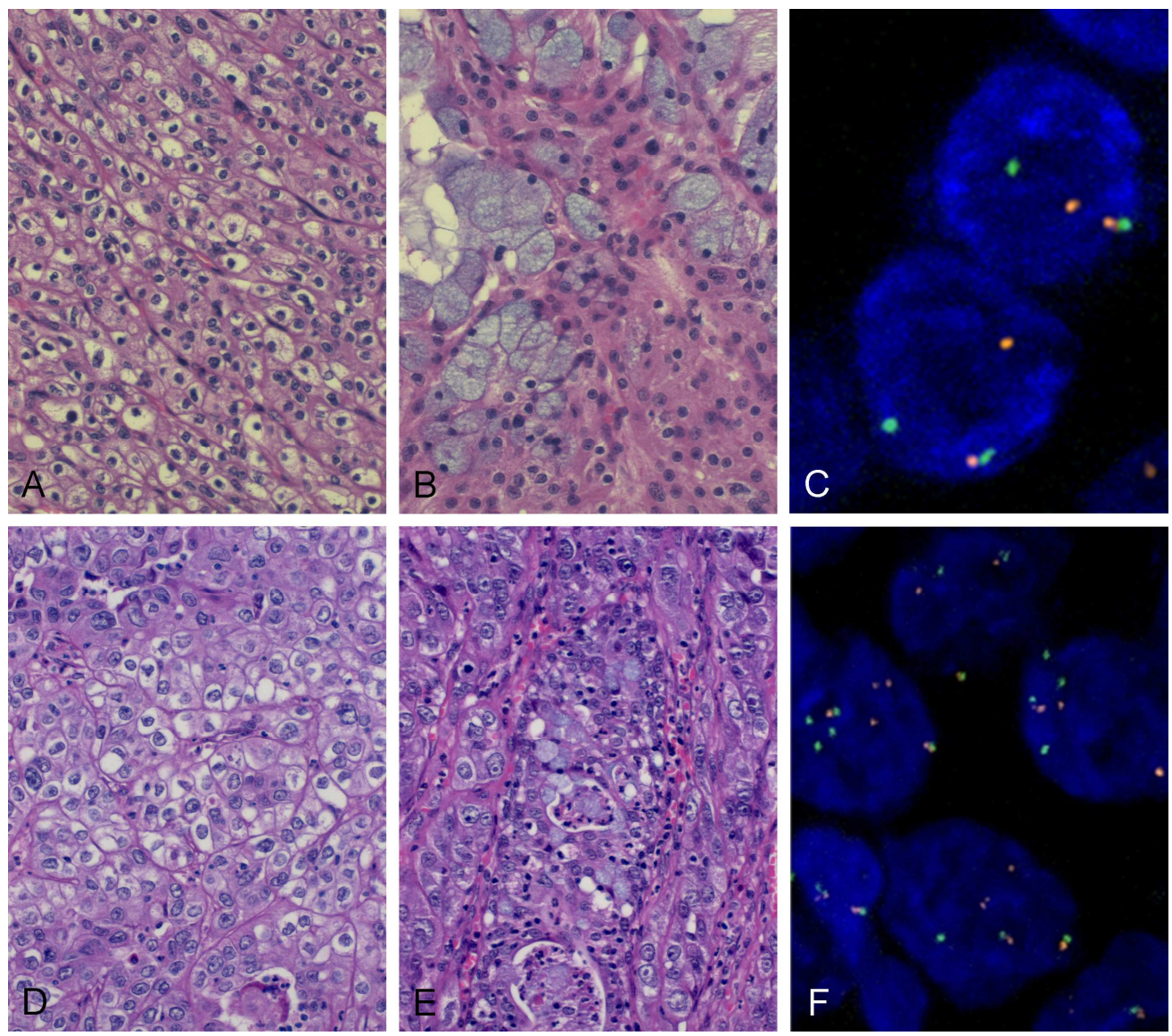

Mucoepidermoid carcinoma of clear cell type. A low-grade MEC predominantly composed of solid sheets of clear cells with inconspicuous nuclei and "chromophobe" appearance. B a small focus with classical morphology detected on further sampling. C FISH using break-apart probes demonstrated translocation $\mathrm{t}(11 ; 19)$ indicated by split orange and green signals. D High grade clear cell MEC with higher nuclear pleomorphism and focal well differentiated areas (E). F FISH demonstrated polysomy 11 and bi- or tri-allelic translocation $\mathrm{t}(11 ; 19)$.

$736 \times 647 \mathrm{~mm}(96 \times 96 \mathrm{DPI})$ 

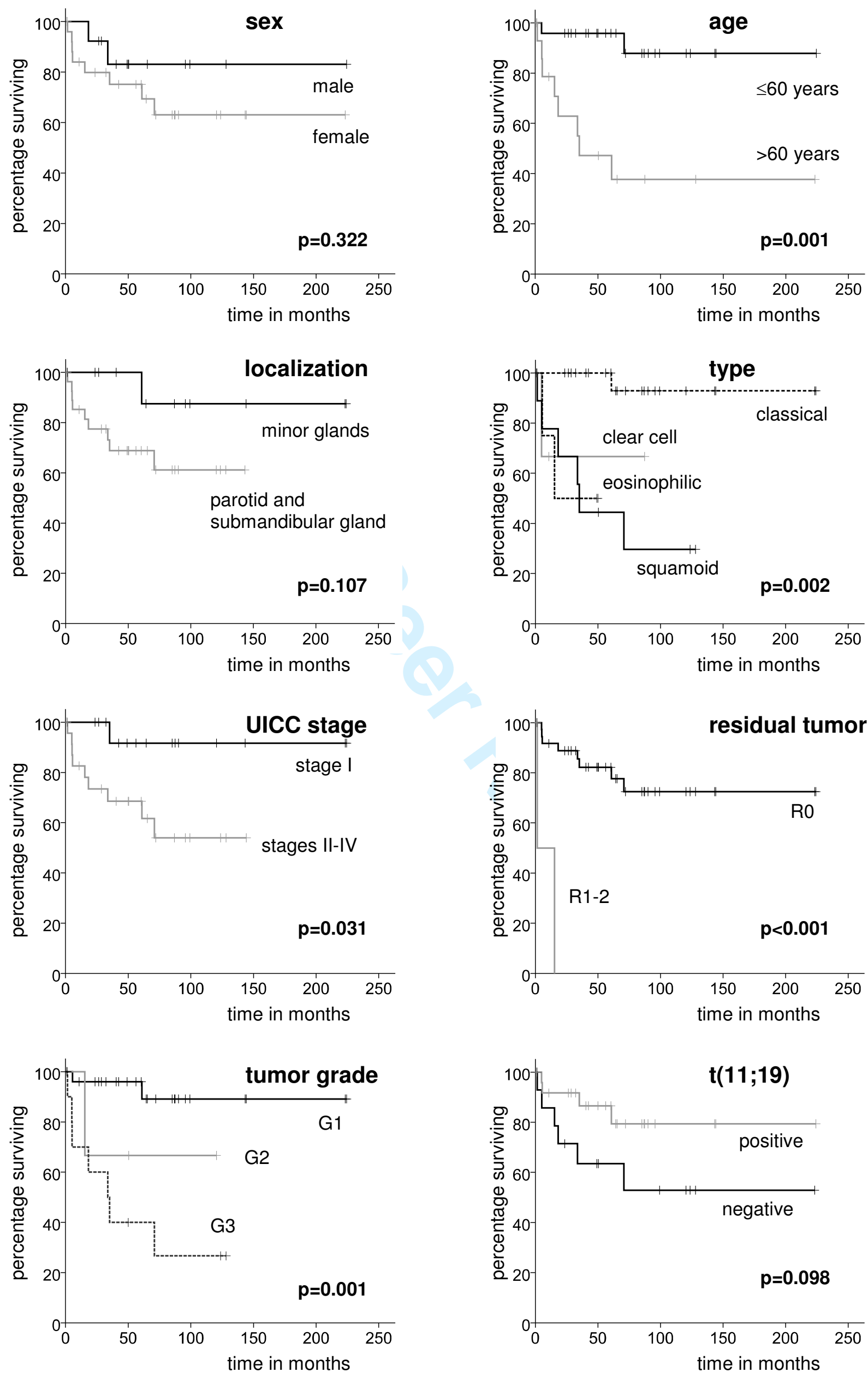
Table 1: Clinicopathologic parameters related to the four subtypes of MEC (Significance of associations was evaluated by Fisher exact test).

\begin{tabular}{|c|c|c|c|c|c|c|c|}
\hline & & $\begin{array}{l}\text { classical } \\
\text { type } \\
(n=23)\end{array}$ & $\begin{array}{l}\text { clear cell } \\
\text { variant } \\
(n=3)\end{array}$ & $\begin{array}{l}\text { eosinophilic } \\
\text { variant } \\
(n=5)\end{array}$ & $\begin{array}{l}\text { squamoid } \\
\text { variant } \\
(\mathrm{n}=9)\end{array}$ & $\begin{array}{l}\text { Fisher } \\
\text { exact Test } \\
\text { classical vs. } \\
\text { others } \\
\end{array}$ & $\begin{array}{l}\text { Fisher } \\
\text { exact Tes } \\
\text { squamoid } \\
\text { vs. others }\end{array}$ \\
\hline \multirow[t]{2}{*}{ age } & $\leq 60$ years $(n=24)$ & 19 & 1 & 2 & 2 & \multirow[t]{2}{*}{$p<0.001$} & \multirow[t]{2}{*}{$p=0.03$} \\
\hline & $>60$ years $(n=16)$ & 4 & 2 & 3 & 7 & & \\
\hline \multirow[t]{2}{*}{ sex } & males $(n=13)$ & 7 & 0 & 2 & 4 & \multirow[t]{2}{*}{ n.s. } & \multirow[t]{2}{*}{ n.s. } \\
\hline & females $(n=27)$ & 16 & 3 & 3 & 5 & & \\
\hline \multirow[t]{3}{*}{ site } & parotid gland $(n=24)$ & 10 & 2 & 4 & 8 & \multirow[t]{3}{*}{$\mathrm{p}=0.125^{\mathrm{a}}$} & \multirow[t]{3}{*}{$\mathrm{p}=0.055^{\mathrm{a}}$} \\
\hline & submandibular gland $(n=4)$ & 2 & 1 & 0 & 1 & & \\
\hline & oral cavity $(n=12)$ & 11 & 0 & 1 & 0 & & \\
\hline \multirow[t]{4}{*}{ stage } & $I(n=16)$ & 12 & 1 & 2 & 1 & \multirow[t]{4}{*}{$p=0.107^{b}$} & \multirow[t]{4}{*}{$\mathrm{p}=0.061^{\mathrm{b}}$} \\
\hline & II $(n=12)$ & 5 & 1 & 2 & 4 & & \\
\hline & III $(n=6)$ & 2 & 0 & 1 & 3 & & \\
\hline & IV $(n=6)$ & 4 & 1 & 0 & 1 & & \\
\hline \multirow[t]{3}{*}{ grade } & $1(n=27)$ & 22 & 2 & 3 & 0 & \multirow[t]{3}{*}{$\mathrm{p}<0.001^{\mathrm{c}}$} & \multirow[t]{3}{*}{$\mathrm{p}<0.001^{\mathrm{c}}$} \\
\hline & $2(n=3)$ & 1 & 0 & 1 & 1 & & \\
\hline & $3(n=10)$ & 0 & 1 & 1 & 8 & & \\
\hline \multirow[t]{3}{*}{ residual tumor } & 0 & 22 & 3 & 4 & 8 & \multirow[t]{3}{*}{ n.s. ${ }^{d}$} & \multirow[t]{3}{*}{ n.s. ${ }^{d}$} \\
\hline & 1 & 0 & 0 & 1 & 0 & & \\
\hline & 2 & 1 & 0 & 0 & 1 & & \\
\hline \multirow[t]{3}{*}{$t(11 ; 19)$} & negative & 4 & 0 & 3 & 8 & \multirow[t]{2}{*}{$p=0.003$} & \multirow[t]{2}{*}{$p=0.001$} \\
\hline & positive & 19 & 3 & 2 & 1 & & \\
\hline & number of cases & 23 & 3 & 5 & 9 & & \\
\hline
\end{tabular}

${ }^{a}$ major glands vs. minor glands

${ }^{\mathrm{b}}$ stage I vs. stages II, III and IV

${ }^{c}$ grade 1 vs. grades 2 and 3

${ }^{d}$ residual tumor 0 vs. residual tumor 1 and 2 
Table 2: Clinicopathologic parameters related to presence or absence of $t(11 ; 19)$. Significance of association was evaluated by Fisher exact test.

\begin{tabular}{|c|c|c|c|c|}
\hline & & $\begin{array}{l}\mathrm{t}(11 ; 19) \\
\text { negative }\end{array}$ & $\begin{array}{l}\mathrm{t}(11 ; 19) \\
\text { positive }\end{array}$ & $\begin{array}{l}\text { Fisher } \\
\text { exact Test }\end{array}$ \\
\hline age & $\begin{array}{l}\leq 60 \text { ys }(n=24) \\
>60 \text { ys }(n=16)\end{array}$ & $\begin{array}{l}6 \\
9\end{array}$ & $\begin{array}{l}18 \\
7\end{array}$ & $p=0.094$ \\
\hline sex & $\begin{array}{l}m(n=13) \\
f(n=27)\end{array}$ & $\begin{array}{l}6 \\
9\end{array}$ & $\begin{array}{l}7 \\
18\end{array}$ & n.s. \\
\hline site & $\begin{array}{l}\text { parotid gland }(n=24) \\
\text { submandibular gland }(n=4) \\
\text { oral cavity }(n=12)\end{array}$ & $\begin{array}{l}9 \\
2 \\
4\end{array}$ & $\begin{array}{l}15 \\
2 \\
8\end{array}$ & n.s. ${ }^{a}$ \\
\hline stage & $\begin{array}{l}\text { I }(n=16) \\
\text { II }(n=12) \\
\text { III }(n=6) \\
\text { IV }(n=6)\end{array}$ & $\begin{array}{l}5 \\
5 \\
3 \\
2\end{array}$ & $\begin{array}{l}11 \\
7 \\
3 \\
3\end{array}$ & n.s. ${ }^{b}$ \\
\hline grade & $\begin{array}{l}1(n=27) \\
2(n=3) \\
3(n=10)\end{array}$ & $\begin{array}{l}5 \\
3 \\
7\end{array}$ & $\begin{array}{l}22 \\
0 \\
3\end{array}$ & $p=0.001^{c}$ \\
\hline residual tumor & $\begin{array}{l}\text { R0 }(n=37) \\
\text { R1 }(n=1) \\
\text { R2 }(n=2)\end{array}$ & $\begin{array}{l}13 \\
1 \\
1\end{array}$ & $\begin{array}{l}24 \\
0 \\
1\end{array}$ & n.s. ${ }^{d}$ \\
\hline & number of cases & 15 & 25 & \\
\hline
\end{tabular}

a major glands vs. minor glands

${ }^{b}$ stage I vs. stages II, III and IV

${ }^{c}$ grade 1 vs. grades 2 and 3

${ }^{d}$ residual tumor 0 vs. residual tumor 1 and 2 
Table 3. Univariate and multivariate Cox regression with reverse stepwise selection. In the upper half age, stage, grade, and residual tumor are included, in the lower half grade is replaced by tumor type (squamoid vs. others).

\begin{tabular}{|c|c|c|c|c|c|c|}
\hline & & univariate & $\begin{array}{l}\text { multivariate } \\
\text { step 1 }\end{array}$ & step 2 & hazard ratio & $95 \%$ confidence interval \\
\hline age & $\leq 60$ ys $(n=24)$ vs. $>60$ ys $(n=16)$ & 0.005 & $p=0.06$ & $p=0.05$ & 5.1 & $1.0-26.9$ \\
\hline stage & stage I $(n=16)$ vs. stages II-IV $(n=24)$ & 0.064 & $p=0.32$ & & & \\
\hline grade & grade $1(n=27)$ vs. grades $2-3(n=13)$ & 0.004 & $\mathrm{p}=0.11$ & $p=0.04$ & 5.4 & $1.1-28.4$ \\
\hline residual & R0 ( $n=37)$ vs. $R 1-2(n=3)$ & 0.001 & $p=0.13$ & $p=0.10$ & 4.7 & $0.74-30.0$ \\
\hline age & $\leq 60$ ys $(n=24)$ vs. $>60$ ys $(n=16)$ & 0.005 & $p=0.09$ & $\mathrm{p}=0.10$ & 4.3 & $0.8-24.0$ \\
\hline stage & stage I ( $n=16)$ vs. stages II-IV ( $n=24)$ & 0.064 & $\mathrm{p}=0.31$ & & & \\
\hline variant & squamoid $(n=9)$ vs. others $(n=31)$ & 0.007 & $p=0.12$ & $p=0.05$ & 4.7 & $1.0-20.7$ \\
\hline residual & R0 ( $n=37)$ vs. $R 1-2(n=3)$ & 0.001 & $p=0.02$ & $p=0.01$ & 18.0 & $2.1-152.8$ \\
\hline
\end{tabular}

